\title{
Monika Samborowska
}

An Independent Author

\section{Andrzej Dawidczyk}

Police Academy in Szczytno, Poland

\section{Turkish Government Policy towards Independent Media after the Failed July 2016 Coup d'État}

Abstract

The article presents the state of the Turkish media, as well as the actions taken by them before and after the failed attempt of the coup d'état in 2016. Pointing to the issue of freedom of speech in Turkey, the article highlights the numerous violations of the right to freedom of expression, which have repeatedly become part of the actions of central government authorities.

Keywords: freedom of speech, free media, authoritarianism

Creating the English-language version of the journal "Securitologia" is financed under contract No. 724/P. DUN/2018 from the funds allocated by the Minister of Science and Higher Education for dissemination of science. 


\section{Introduction}

The subject of this article is dictated by the need to identify the current state of media functioning in the Republic of Turkey due to the political situation created after the attempt of the coup d'état in 2016. The indirect motivation for the creation of this article is the shortage of scientific publications concerning the presented situation, illustrating and addressing the problem of the state of the media in question, both in Polish and foreign scientific literature.

The main research problem is as follows: how did the coup attempt made on 15-16 July 2016 in Turkey affect the current state of Turkish media? In particular, it was decided to answer the following questions: are there noticeable dependencies and correlations between the current state of Turkish media and the establishment of power in Turkey and what are they? Is the Turkish government responsible for the current state of the Turkish media and what is its responsibility? Finally, to what extent and in what way does the government activity directly influence the Turkish media and what may be the possible further effects of this influence?

The aim of the article is, therefore, to present a reliable picture of the functioning of Turkish media in recent years, the image that reflects the level of freedom of speech, which is currently challenged by known entities dealing with the study of this issue around the world.

Analysis of the mentioned research problems will allow to confirm or refute the major hypothesis that the situation of the media in Turkey has significantly deteriorated after the coup attempt on 15-16 July 2016. And also the sub-hypotheses: there are relations between the current state of Turkish media and the government of power in Turkey; the Turkish government bears direct responsibility for the current situation of Turkish media and has a straight impact on it; the state of Turkish media continues to deteriorate without visible chances for improvement.

The article has been divided into three main parts. The first part is devoted to explaining and defining the role played by the media in the functioning of contemporary political systems and their citizens. This part presents and analyses the image of Turkish media and its functioning over the last few years before attempting a coup d'état. The second part of the article examines and describes the impact of the coup attempt process on the functioning of the media system of Turkey. It also presents the situation of 
the Turkish media a few months before the attempt of the coup. The third part of the article provides an in-depth characterisation of the direct and indirect effects of the attempt of a coup d'état and its impact on the current area of the state of media in Turkey. There is particular attention to and description of numerous violations of the right of freedom of speech and expression that have repeatedly become the participation of central government authorities.

The most valued Polish authorities writing on the problems of contemporary Turkey, to which the reader can be referred, are Franciszek Gołembski ${ }^{1}$, Adam Szymański ${ }^{2}$, Dariusz Kołodziejczyk ${ }^{3}$ and Justyna Misiagiewicz ${ }^{4}$. Despite those authors, in comparison to foreign literature, Polish literature still experiences a shortage of scientific publications related to the issue of freedom of speech in the Turkish media. Due to the currently insufficient number of such studies, the majority of scientific literature and sources used to write the article are mainly publications and reports of independent international organisations and entities that have a well-established position and a solid reputation in the international arena.

\section{The functioning of Turkish media in 2009-2017}

Undoubtedly, free media is one of the most significant foundations of the democratic system and, at the same time, its flagship. Free media is prerequisites for freedom of speech and for that reason it should be properly understood, not idealised because it can grow to the rank of myth, according to which, in the consciousness of many audiences, listeners and viewers freedom of speech identifies automatically with its truthfulness and objectivity (Drożdż 2006, p. 191).

According to Piotr Bielawski, the two most important factors affecting the functioning of mass media are legal regulations and good habit (2011, p. 92). In democratic systems, the protection of this freedom includes all kinds of statements expressing opinions, ideas or information - regardless of their content and manner of communication. This also applies to the freedom of artistic expression, commercial information, popular music and advertisements broadcast using a cable network.

\footnotetext{
${ }_{1}^{1}$ Among others: Gołembski F. (1994), Droga Turcii do Unii Europejskiej, Warszawa, PISM.

${ }^{2}$ Szymański A. (2013), Turcja $i$ Wyzwania i seanse, Warszawa, PISM.

${ }^{3}$ Kołodziejczyk D. (2011), Turcja, Warszawa, TRIO.

${ }^{4}$ Misiagiewicz J. (2009), Polityka zagranična Turgï po zimnej wojnie, Toruń, Wydawnictwo Adam Marszałek.
} 
In democratic states, the media is a platform for public communication with political and state institutions. In non-democratic countries, however, they remain in close relations with political power. In this case, the media is regarded as a tool for controlling society. Regardless of how the media are used, they derive their power from key entities of public space - from society, citizens, politicians, rulers, state officials, etc. (Gackowski 2013, p. 20). In such a system, media power is considered to be secondary. Its basis is the conviction of entities with real power that the media can influence the public. By buying newspapers, watching TV and listening to the radio, the society legitimises media intervention in contacts with the government. Correspondingly the political elites, while hosting the press and television broadcasts, are convinced that the media give them the opportunity to communicate effectively and influence society (Ibidem, pp. 20-21).

The existence of television and its role are significant in shaping public opinion. Italian political theorist Giovanni Sartori states that television plays a demiurge role in society, providing people with information and news, but not concepts or ideas. In work devoted to the influence of television on democracy, Sartori considers the question of how video politics affects rulers and voters. He minds that it is difficult to investigate this impact precisely. This is due to the fact that there are no comparative counterfacts, i.e. examples of social life existing without television that could be examined (2007, pp. 33-35).

These analyses show that the impact of television on voters is enormous. Such a state of affairs comes from the specificity of the medium, which is television, as well as the way in which today's societies function. Today's election campaigns are conducted mainly on television. The specificity of this medium makes campaigns highly personalised. It results that the viewer does not listen to debates about programs proposed by parties, but watches and listens to specific politicians who speak very briefly - there is no time for deepened substantive discussions in mass media. Viewers are not adequately prepared to follow and understand such conversations in the right way. Television also influences politicians and determines the way of practising politics. In former times, politicians largely remained de-pendent on the party structures to which they belonged. In the age of television, this addiction has ceased to have greater significance, because through television politicians reach voters quickly and without intermediaries. The best example given by Sartori is the former Italian Prime Minister Silvio Berlusconi, who 
won a quarter of the Italian votes without the support of any organised party but owning the great television empire (Ibidem, pp. 52-55).

Turkey's current president, Recep Tayyip Erdogan, also enjoys significant support among the vast majority of social groups in his country. Unfortunately, the freedom of the Turkish media is unequivocally very low in the reports of all international organisations dealing with the area of free and independent media. In Turkey, there is a greater tendency of the media to cooperate with the central authorities. This problem mainly concerns state media.

Independent domestic and foreign press media presented different views and opinions in their pages, which included both a criticism of President Erdogan's party governments and himself. However, this does not change the situation that there was a high rate of transmission of information in Turkish press media, which opposed to being considered independent. In 2015, Turkish radio and television were as numerous as press. They had a large percentage of private stations and TV channels transmitted both terrestrially and by satellite. State television and radio broadcasted some programs containing content in the languages of national minorities, along with several local radio stations that transmitted programs in Kurdish. Since 2009, the Internet radio station Nor Radio, broadcasting in Armenian, has been legally established in Turkey for the first time.

Freedom of media in Turkey began to significantly worsen its quality at an alarming rate since 2014. Government laws and the changes introduced not only in media and press law but also in Turkish law and anti-terrorism law, the introduction of Internet censorship and the tightening of the criminal legislature for defamation imposed by President Erdogan have resulted in numerous forms of stigmatisation and prosecution of many journalists and independent of intimidation, persecution, violence, search and requisition of personal items, dismissal, arrest and fictitious charges.

After a failed coup in July 2016, Turkey's pressure on the journalistic environment has not weakened and also rapidly increased. The Turkish authorities effectively and precisely continue to exert pressure using legal, financial and administrative leverage mechanisms to take control of private media and to silence conflicting and unfavourable views of the government (Freedom House 2016). 
Table 1. Ranking of press freedom in the world in 2017 (selected countries)

\begin{tabular}{clc}
\hline Position in the ranking & Country & Number of points recived \\
\hline 1 & Norway & 7,63 \\
\hline 2 & Sweden & 8,31 \\
\hline 3 & Netherlands & 10,01 \\
\hline 4 & Finland & 10,26 \\
\hline 5 & Switzerland & 11,27 \\
\hline 6 & Jamaica & 11,33 \\
\hline 7 & Belgium & 13,16 \\
\hline 8 & New Zealand & 13,62 \\
\hline 9 & Denmark & 13,99 \\
\hline 10 & Costa Rica & 14,01 \\
\hline 15 & Germany & 14,39 \\
\hline 27 & Slovakia & 20,26 \\
\hline 31 & Spain & 20,51 \\
\hline 33 & France & 21,87 \\
\hline 40 & Great Britain & 23,25 \\
\hline 58 & Poland & $\mathbf{2 6 , 5 9}$ \\
\hline 73 & Hungary & 29,11 \\
\hline 74 & Greece & 29,19 \\
\hline 155 & Turkey & 53,50 \\
\hline
\end{tabular}

Source: Reporters without Borders 2018.

Referring to the area of freedom of expression in the Republic of Turkey, it can be pointed out that since 2016; there are constant reports that the liberty of speech in the Turkish State is more and more decreasing. Since the time of taking power in this country by the former Prime Minister and now the President, Recep Tayyip Erdogan, one could observe a successive process of taking control of the media in this country.

This information is confirmed by the reports of the organization Reporters Without Borders. In the ranking published in April 2018, reflecting the level of freedom of 
speech in 2017, Turkey ranked 157th (on 180 classified countries). For comparison, Poland was ranked 58th in that ranking. In just two years, both Turkey and Poland recorded severe relegation positions, because in 2015 Turkey held the place of 151 with the number of points 50.76, and Poland was on the 47th place with 23.89 points (Reporters without-Borders 2018). These situations indicate a critical regression of these countries in the area of freedom of speech and expression (Table 1).

\section{The situation of Turkish media during the coup attempt in 2016}

Data on the proceedings initiated in connection with insulting the president is further evidence that freedom of expression in the Turkish state undergoes systematic limitation. Opinions criticising the leader of the Justice and Development Party (Turkish Adalet ve Kalkama Partisi, AKP) cannot be presented in the public media, as the current Turkish president has repeatedly summoned journalists, who articulated their views about him in a caricatural or disrespectful manner, to court.

Since 2014, i.e. since Erdogan took over the office of President, more than 2,000 crimi-nal proceedings have been registered in Turkey (data from April 2016) due to the insult of the head of state (Jakubczak 2017).

An example of this is the case of a 16-year-old student from the city of Konya, who was sentenced by article 299 of the Turkish Criminal Code in December 2014 by a juvenile court for 11 months and 20 days imprisonment for insulting Erdogan, calling him "a thief who became the owner of the presidential palace illegally" (BBC 2014).

Another example of the affront of the head of state, which this time echoed in all major international media, was the broadcast on the German public television ZDF on 31 March 2016, during the ongoing Neo Magagin Royal programme, a satirical poem that offends - President Erdogan and presents him in a very ridiculous, mockery and in fragments vulgar way. The journalist, author and presenter of the satire was a controversial journalist Jan Boehmermann, known for his language. A week after the broadcast, Boehmermann received one of the most prestigious and significant television prizes awarded annually in Germany - the Adolf Grimm Award (Deutsche Welle 2017).

The satire offending the President of Turkey aroused great emotions and mixed feelings on the international arena, not only in the journalistic community. Extreme reactions in the world have caused that many journalists and political commentators 
began to ask them-selves where the limits of journalist freedom are, and what circumstances must appear to recognise that the border was exceeded.

Turkey immediately reacted very negatively to the presented satire. The Turkish diplomacy demanded that Germany initiate proceedings against Boehmermann. This intention triggered an avalanche of comments among all German society because the vast majority of the citizens also did not like this satire and found it outrageous and scandalous. The wave of criticism of the ZDF station swept across the entire territory of Germany. The German Chancellor, Angela Merkel and the President of the European Parliament, Martin Schulz, also took the floor on that subject. Merkel found satire "deliberately offensive", leaving it to justice (BBC 2016). Schulz, on the other hand, criticised President Erdogan's behaviour, emphasising the need to preserve freedom of speech in a democratic state: "Politicians must endure satire, and this also applies to the Turkish president. Satire is a fundamental element of democratic culture" (Matzke 2016).

In reference to events in Germany, a 27-year-old model, former Miss Turkey Merve Büyüksaraç has published a controversial pamphlet on her social network account on Instagram (Lisowski 2016). The former beauty queen was sentenced a 14 month suspended prison in May 2016. The interpretation of the court's judgement was as follows: "Found guilty of insulting a high-ranking civil servant, which is the office of the President of the Republic of Turkey" (BBC News 2016).

Already in 2014 Erdogan gave a negative opinion on social media in Turkey. The formal manifestation of it was to block the use of Twitter on the territory of the country. At that time, the Prime Minister threatened to "root out" Twitter (Al Jazeera 2014). The blockade was a reaction to the use of Twitter as a tool of criticism of the Turkish Prime Minister.

One such case was the situation of the Azerbaijan journalist and columnist for the "Today's Zaman" daily, Mahir Zeynalov, who was deported to his country in January 2014 by Turkish Court order. The verdict was issued after Erdogan filed an official complaint against a journalist for tweeting links to articles on the corruption scandal in Turkey in December 2013. In March 2014, access to Twitter was blocked for two weeks without a prior court order.

The same month there was a similar situation of the imposition of the blockade, this time on YouTube, the court gave permission to do this only two months after the actual blocking of the portal. 
However, it should be emphasised that the media were used instrumentally also by Erdogan himself. During the coup d'état in July 2016, it was thanks to social media that President Erdogan managed to give a kind of message to the nation. Using the video chat func-ion, the Turkish president, who was at that time on vacation, condemned the behaviour and actions of the military, promising to draw harsh consequences. Simultaneously, he called on his followers to start fighting the conspirators. The message given through the simple FaceTime application that every iPhone user receives in the package proved to be an incredibly effective tool. After listening to Erdogan's words, indignant Turks immediately set off on military tanks, "almost with bare fists” (Zelazińska 2015).

At the same time, the assassins were trying to take control of the public television Turkiye Radyo Televizyon Kurumu (TRT). Founded in 1968, this television for many years has remained an impregnable monopolist on the Turkish media market. The gradual develop-ment of private stations has weakened its position. However, TRT is still the largest public broadcaster in Turkey. In its portfolio, it has the following stations: TRT HD, TRT1HD, TRT Haber HD, TRT Spor and TRT Belgesel. Currently, in the Turkish state, it is perceived through the prism of Erdogan's ally. During the ongoing coup, the military planned to broadcast a special message and shut it down completely. By cutting off Turkish society from the main source of information, the usurpers wanted to cause chaos and disinformation in the internal structure of the state. However, the plan failed, as the President used the already mentioned modern form of communication.

After overcoming the crisis in the country, Erdogan initiated a large-scale prosecution of all those involved in the planned coup d'état. The persecution and repression did not bypass the journalistic community either. The arrest warrants concerned, among others, forty-seven former journalists (including a valued journalist and former Turkish parliamentarian Nazli Ilicak) of the largest private daily Turkish newspaper "Zaman" issued every day in 650,000 copies, which kept in touch with a Muslim scholar, writer, activist for peace, moralist and spiritual guide of the international Hizmet movement, Fethullah Gulen, recognised by the Turkish authorities as the main initiator of the coup d'état (RZ 2016).

Furthermore, Erdogan's actions against this newspaper have been taken several months earlier. They were an expression of a strong consolidation of power in the hands of a single autocratic power, namely the office of the President of Turkey. Using 
the arguments of supporting attacks on the territory of the Republic the Turkish authorities managed to take over the board of one of the leading media groups in Turkey, which was Feza Gazetecilik, the owner of the daily "Zaman", by pressing charges against the editor-in-chief Ekrem Dumanli for the alleged establishment of a terrorist organization (Chudziak 2016).

The appropriation of one of the largest opposing media groups in the country was faced violent reactions and protests from its supporters. In view of the situation, the Turkish authorities were forced to send special police troops to suppress the protest crowd with pepper gas and water cannons. The international opinion responded negatively to these actions. Human Rights Watch and Amnesty International gave their criticism at Erdogan.

The actions of the Turkish authorities have also been strongly reacted by the US Department of State. In response to the West's views, Turkish Prime Minister Ahmet Davutoglu and other ACP representatives tried to deny and persuade that the actions against Feza Gazetecilik had no connection with government actions. However, the acquisition of control over Feza Gazetecilik was another step of the government's struggle against opposition media in Turkey. A few months earlier, using the same operational arrangements, the Koza Ipek Holding media group was taken under control. This group included the daily newspapers "Bugun Gazetesi” and "Millet Gazetesi”, two television stations Kanalturk and Bugun TV, and the Kanalturk Radyo radio station.

As a result of the controlled changes that had taken place in the editorial offices of the mentioned newspapers, there was a drastic drop in sales of their outlays, which in turn led to their bankruptcy. Notably, the takeover of the newspapers took place on 4 March 2016, exactly one week after the publication of the decision of the Constitutional Court of Turkey, which ruled that the detention of two journalists of the opposition newspaper "Cumhuriyet" was illegal (they were charged with espionage and disclosure of state secrets, in retaliation for their publication of an article describing the practice of providing arms by the Turkish government in 2014 armed rebels in Syria, under the pretext of providing humanitarian aid to the wounded and needy).

The independent media community's interpreted struggle against the opposition media as a protest and preventive demonstration of power, both internally and externally in the Turkish state. 


\section{Consequences of the July 2016 coup d'état against the Turkish media community}

It is to be noted that the actions of the Turkish government are supported by the progovernment media sector, e.g. TRT television. These media not only play the role of an intermediary in the transmitting of communications from public authorities but also they often engage in promoting many plans and proposals of the current power, thus legitimising them and giving them their support.

One of such activities was the involvement of pro-government media in the promotion of changes in the Turkish Constitution, which goal was to further strengthen the presidential power in the country. State media pointed out that the specificity of modern times and, above all, the threat of terrorism constitute a sufficient justification and premise for extending the controls of the apparatus of power. In the comparison of values, security versus freedom, pro-government media have given priority to security.

In conclusion, finally, after the failed coup by Erdogan's opponents, the Turkish authorities decided to close: 5 news agencies, 16 television stations (Wprost 2016), 23 radio stations, 45 newspapers, 15 magazines, and 29 publishing houses and distribution companies. CNN Turk provided this information at the end of 2016. For providing information and for broadcasting in a prime time statements of the editor-in-chief of the Diyarbakir Bar Association, Tahir Elçi, clearly stating that the Kurdistan Workers' Party (Kurd. Partiya Karkeren Kurdistane - PKK) is not a terrorist organization, but an armed political movement fighting for Independence of the Kurds community, CNN Turk was fined in the amount of 700 thousand Turkish Liras (230 thousand euros).

A month after giving his opinion, Tahir Elçi himself was assassinated by an unknown perpetrator. That happened after he received a series of death threats and was accused by the Turkish government "of disseminating terrorist propaganda on behalf of the terrorist organisation" (Expression Interrupted 2017). As a result of extending the coup consequences, a total of more than 140 newspapers, television stations, broadcasters and press agencies were closed (Table 2).

In addition, the Turkish court issued a decision to block access to at least 17 news websites owned and operated by the following media entities: Yarına Bakış, Medyascope, Yeni Hayat Gazetesi, Can Erzincan TV, Gazeteport, Haberdar, Karg1 Gazetesi, dokuz8HABER, Jiyan.us, Özgür Gündem, DIHA, and IMC TV. Finally, the court also issued an order to close the Ozguruz.org website, founded by a well-known and valued 
journalist and publicist in Turkey, former editor of "Cumhuriyet", Can Dundar. This page was shut even before the journalist could publish any information and news on it (EKN/TK 2017).

Table 2. Categories of violations of freedom of expression in Turkey in 2013, 2016, 2017

\begin{tabular}{lccc}
\hline Year & 2013 & 2016 & 2017 \\
\hline Blocked websites & 15632 & 104904 & 114000 \\
\hline Closed newspapers & 2 & 45 & 62 \\
\hline Shut down magazines & 5 & 15 & 19 \\
\hline Banned publications & 12 & 29 & 35 \\
\hline Shut down TV stations & 5 & 16 & 32 \\
\hline
\end{tabular}

Source: Amnesty International 2018.

Data on the rapidly growing number of journalists dismissed from work was alerting about the ever-increasing scale of problems with the freedom of the press in Turkey. According to data presented by the Turkish organisation Press for Freedom, which analyses and studies the quality of freedom of speech in Turkey, in five months (from January to May 2016), 894 journalists lost their jobs in Turkey (CPJ 2017). Freedom House in its 2017 report leaves no illusions that free and independent Turkish media do not exist in practice.

In December 2016, the Committee to Protect Journalists confirmed the arrest of 81 journalists and their imprisonment in Turkish custody. In 2017, the number was 73 (CPJ 2017). At the moment, according to the PEN America Center, this figure exceeds more than 150 people (PEN 2018). Among the prisoners were Ahmet Altam ("Taraf"), Mehmet Altam (“Taraf”), Nazli Ilicak (“Sabah”) (Shaheen 2018), Asli Erdogan (“Ozgur Gundem”), Necmiye Alpay (“Ozgur Gundem”), Zehra Dogan (“Jinha”), Ibrahim ayegen ("Zaman"), Mehmet Ozdemir ("Zaman"), Emre Soncan ("Zaman") (IFJ 2018). This precedent has led Turkey to become the world leader in an inglorious ranking in terms of enslavement of the media environment.

Turkish Platform for Independent Journalism reported the number of 145 journalists arrested. Furthermore, it reported about 2700 media sector workers who were either 
fired or forced to resign. Hundreds of journalists lost their press credentials. An unknown number of journalists had their passports revoked and were forbidden from leaving the country. Fifty-four journalists had their property confiscated (Freedom House 2017).

In October 2016, Turkish police arrested Murat Sabuncu, the new editor-in-chief of "Cumhuriyet" and at least 14 of its employees (SCF). They were accused of supporting terrorist organisations, including the PKK, by posting tweets and headlines in the newspaper in which theyminority defended by journalists (Expression Interrupted 2018).

In November 2016, Sabuncu and other employees in custody were formally accused of supporting criminal groups, where they were officially awaiting the outcome of legal proceedings against them (Gumrukcu, Solaker 2016). Journalists were threatened with of up to 15 years of imprisonment. Finally, in April 2018, the Turkish court sentenced Murat Sabuncu and investigative journalist Ahmet Sik to 7.5 years imprisonment. The president of "Cumhuriyet", Akin Atalay, was sentenced to 8 years in prison. The remaining 11 newspaper employees got a similar sentence (Deutsche Welle 2017).

"Cumhuriyet" remains the only active, fully independent newspaper in Turkey that successfully resists the government and its actions in the fight for free and independent media in Turkey. However, the price that journalists pay for this fight is very high, because it is their own life and freedom (Gall 2018).

25 journalists employed in this agency have been put in custody. Since August 2016, the censorship of online information, news and content shared on social media platforms has increased significantly. YouTube, Twitter and Facebook have again been temporarily blocked. These restrictions concerned the entire territory of the country, with clear exacerbation in the south-eastern regions inhabited by the Kurdish minority. The total ban on Internet access in these regions was in effect in October and November 2016. It was a punishment for the protests of the population in retaliation for the arrest of local Kurdish activists.

Another nationwide blockade of the popular WhatsApp application, use to communicate, also took place in November 2016. According to the opinion of the independent Turkish organisation Engelli Web, the total number of blocked websites in Turkey at the end of 2016 reached over 115 thousand (Freedom House 2017). The American organisation Freedom House, working for the freedom of speech and global media, publishing annually independent reports on the state of the media and press in 
Turkey, has consecutively issued a status on the lack of freedom of speech in this country, consistently maintained since 2014 (Table 3). Moreover, in October 2016, the Turkish government approved another form of financial repression relating to the media sector.

Table 3. Freedom of the press and media in Turkey in 2007-2017

\begin{tabular}{llccc}
\hline Years & $\begin{array}{l}\text { Status of freedom } \\
\text { of press and media }\end{array}$ & $\begin{array}{c}\text { Index of press } \\
\text { freedom (points) }\end{array}$ & $\begin{array}{c}\text { Index of Internet } \\
\text { freedom (points) }\end{array}$ & $\begin{array}{c}\text { Index of access to } \\
\text { the internet }\end{array}$ \\
\hline 2007 & Partly free & 49 & No data data & 29 \\
\hline 2008 & Partly free & 51 & 49 & 34,37 \\
\hline 2013 & Partly free & 56 & 55 & 46,25 \\
\hline 2014 & Not free & 62 & 54 & 51 \\
\hline 2015 & Not free & 65 & 58 & 53,7 \\
\hline 2016 & Not free & 71 & 58,4 & 76 \\
\hline 2017 & Not free & 76 & & 56 \\
\hline
\end{tabular}

* Scale score from 0-100 points, where o stands for the best situation and 100 for the worst.

Source: Own development based on Freedom House reports 2007-2008 and 2013-2017.

Organ Basin Ilan Kurumu, responsible for controlling the allocation of public announcements and advertisements, introduced new regulations regarding the inability to use state owned advertisements for newspapers and magazines which owners, managers or employees were suspected or charged with legal charges for links with terrorist groups, or accused of working with them.

\section{Summary}

The analysis of the above examples indicates that the quality of Turkish democracy is still insufficient and leaves much to be desired given the aspect of freedom of expression presented in the Turkish media. The events related to the coup attempt carried out on the night between 15 and 16 July 2016 are another Erdogan's argument explaining 
the fight against disobedient representatives of the media world. The Turkish opposition and journalists persecuted in Turkey see the accession of their country to the EU as a chance to improve the situation in the country.

The considerations presented in the article clearly show that the freedom of a press in the country upon the Bosporus is severely restricted. The central authorities argue that its fight against the opposition media comes from the need to protect the interests of the state against the increasing phenomenon of international and internal terrorism. However, external observers have no doubts and agree that this is how President Erdogan and his colleagues are massively removing journalists who are unfavourable to the government. Pressure from external entities proves to be far ineffective. The Turkish authorities continue the process of fighting the independent media.

Consequently, it is justified to implement more radical and effective measures to eliminate or at least reduce this process to a certain extent. However, it is difficult to point out a potential entity that would put powerful pressure on Turkey, while the EU, currently struggling with the largest immigration crisis in the history and due to jointly undoubtedly huge participation of Turkey in its effective inhibition, will be reluctant to intervene and engage in the internal affairs of the country.

The exercise of power by the current President of the Republic of Turkey, Recep Tayyip Erdogan, and his recent attempts to gradually appropriate the media sphere prove that in Turkey there are visible manifestations of the elements of the autocratic system, which have drastically intensified after a coup attempt. The main reasons and interests of the Turkish government in the fight against freedom of speech are: the will to exercise undivided power, the elimination of political opposition, the exercise of complete control over the Turkish society, the fear of losing power and political failure in the elections, and the desire to maintain the unity and indivisibility of the state in fear of the problems of the national minorities inhabiting the territory of the Turkish state (mainly the problem of the Kurdish minority, which demands rights, autonomy and the creation of an independent state).

The partial suspension by the Republic of Turkey at the end of July 2016 of compliance with the European Convention on Human Rights, the desire to restore the death penalty, amend the constitution and introduce the presidential system, as well as the arrest of people distinguished by good repute on the international stage, and finally, the 
currency crisis and the high inflation facing Turkey pose a serious question about the future of the country.

Each of the three parts of the article sought to respond to separate research problems, nonetheless concerning the common question of the current state of the Turkish media and the role played by the Turkish authorities in this state. The conclusions resulting from the article are as follows.

Firstly, the attempted coup in Turkey has radically influenced the current state of the Turkish media. Secondly, the legislation on the independent media sector has been tightened up. Thirdly, an intensified censorship of freedom of speech and expression has been introduced in the territory of the Republic of Turkey. Consequently, the independent Turkish media have ceased to exist in practice. Simultaneously, the aim of the article was reached to determine the actual picture of Turkish media in a few years before the attack.

The paper confirmed sub-hypotheses, which led to the formulation of the following conclusions and outcomes occurring from the analysed state of affairs:

- freedom of speech and expression is currently not respected in Turkey;

- fundamental human rights and freedoms directly related to the issue of freedom of expression are being violated;

- the Turkish government bears direct responsibility for the continually deteriorating situation of the media in Turkey, resulting from the attempted coup d'état of July 2016;

- this government continues to pursue a policy of media repression and censorship against journalists and employees of the media sector in Turkey, without taking any action to improve or partially improve the situation.

\section{References}

Al Jazeera (2014), Turkey's Erdogan threatens to ban Twitter, http:/ /www.aljazeera.com/ news/europe/2014/03/turkey-erdogan-threatens-ban-twitter-20143201659567324 67.html [19.09.2017]

Amnesty International (2018), Turkey 2017/2018, https://www.amnesty.org/en/countries/europe-and-central-asia/turkey/report-turkey/ [17.03.2018] 
BBC (2014), Turkey teenager accused of insulting president released, http:/ /www.bbc.com/ news/world-europe-30603709 [19.09.2017]

BBC News (2016), Ex-miss Turkey sentenced for insulting Erdogan, http:/ /www.bbc. com/news/world-europe-36419723 [19.08.2017]

Bielawski P. (2011), Wolność to odpowiedzialnośc: uwagi do systemu medialnego - fundamentu demokracii, [w:] Praktyczne aspekty wolności wypowiedzi, (red.) Lis W., Husak Z., Toruń, Wydawnictwo Adam Marszałek

Chudziak M. (2016), Kolejna odsłona walkei z mediami w Turcji, http:/ /www.osw.waw.pl/ $\mathrm{pl}$ /publikacje/analizy/2016-03-09/kolejna-odslona-walki-z-mediami-w-turcji [05.08.2017]

CPJ (2017), Turkey, Europe, Central Asia, https://cpj.org/europe/turkey/ [02.03.2017]

Deutsche Welle (2017), Turkey: Opposition Cumburiyet journalists sentenced to jail on terror charges, http:/ / www.dw.com/en/turkey-opposition-cumhuriyet-journalists-sentenced-tojail-on-terror-charges/a-43537883 [12.05.2018]

Drożdż M. (2006), Etycẓne orientacje w mediosferze, Tarnów, Biblos

EKN/TK (2018), Ozguruz.org Blocked Before Site Could Publish Any News, bianet.org, http:/ /bianet.org/english/media/183060-ozguruz-org-blocked-before-site-couldpublish-any-news [31.05.2018]

Expressioninterrupted (2017), Journalists in jail, https:/ / expressioninterrupted.com/ census / [06.03.2018]

Expressioninterrupted (2018), Murat Sabuncu, https://expressioninterrupted.com/murat-sabuncu/ [03.06.2018]

Freedom House (2007), Turkey. Freedom of the Press 2007, https:/ / freedomhouse.org/report/freedom-world/2007/turkey [17.05.2018]

Freedom House (2008), Turkey. Freedom of the Press 2008, https:/ / freedomhouse.org/report/freedom-world/2008/turkey [17.05.2018]

Freedom House (2013), Turkey. Freedom of the Press 2013, https:/ / freedomhouse.org/report/freedom-world/2013/turkey [17.05.2018]

Freedom House (2014), Turkey. Freedom of the Press 2014, https:/ / freedomhouse.org/report/freedom-world/2014/turkey [17.05.2018]

Freedom House (2015), Turkey. Freedom of the Press 2015, https:/ / freedomhouse.org/report/freedom-press/2015/turkey [17.05.2018] 
Freedom House (2016), Turkey. Freedom of the Press 2016, https://freedomhouse.org/report/freedom-press/2016/turkey [17.05.2018]

Freedom House (2017), Turkey. Freedom of the Press 2017, https://freedomhouse.org/report/freedom-press/2017/turkey [17.05.2018]

Gackowski T. (2013), Władza na dywaniku. Jako polskie media rozliczaja polityków, Toruń, Wydawnictwo Adam Marszałek

Gumrukcu T., Solaker G. (2016), Journalists arrested as Ankara steps up crackdown on dissent, „The Guardian”, https://www.theguardian.com/world/2016/nov/05/erdogancumhuriyet-turkey-journalists-arrested-detained-dissent

IFJ (2018), Two to seven years prison terms for Zaman journalists, http://www.ifj.org/nc/ne ws-single-view/backpid/50/article/turkey-two-to-seven-years-prison-terms-for-zaman-journalists/ [01.06.2018]

Jakubczak D. (2017), Cyy Ankara planuje dalsze ograniczenie wolności stowa?, http://www. dw.com/pl/czy-ankara-planuje-dalsze-ograniczenie-wolno \%C5\%9Bci-prasy-i-s\% C5\%82owa/a-19215210 [03.08.2017]

Lisowski E. (2016), Former Miss Turkey Convicted of Insulting President Erdogan, University of Central Florida Global Perspectives, https://ucfglobalperspectives.org/formermiss-turkey-convicted-of-insulting-president-erdogan/ [19.09.2017]

Matzke M. (2016), Ostra krytyka szefa PE: Erdogan sie zagalopowat, „Deutsche Welle”, http://www.dw.com/pl/ostra-krytyka-szefa-pe-erdogan-si \%C4\%99-zagalopowa\% C5\%82/a-19161160 [19.09.2017]

Gall C. (2018), Turkey's Independent Newspaper Voice Perseveres With a Smile, „The New York Times", https://www.nytimes.com/2018/05/06/world/europe/turkeycumh uriyet.html [03.06.2018]

PEN (2018), Turkey. The freedom to write, https://pen.org/advocacy-campaign/turkeyworlds-worst-jailer-journalists/ [10.06.2018]

Reporters without Borders (2018), 2018 World Press Freedom Index, https://rsf.org/en/ ranking $/ 2018$

RZ (2017), Turcja: nakasy aresztowania dziennikaryy powiqzanych z.Fetbullahem Gulenem, Onet.pl, http://wiadomosci.onet.pl/swiat/turcja-nakazy-aresztowania-dziennikarzy-powiazanych-z-fethullahem-gulenem/hee39q [05.08.2017]

Sartori G. (2007), Homo Videns. Telewizja i post-myślenie, Warszawa, Wydawnictwo Uniwersytetu Warszawskiego 
SCF (2018), Turkish court sentences 14 Cumburiyet daily staff members to prison over terror charges, Stockholm Center for Freedom, https://stockholmcf.org/turkish-court-sentences14-cumhuriyet-daily-staff-members-to-prison-over-terror-charges [29.04.2018]

Shaheen K. (2018), Turkey sentences journalists to life in jail over coup attempt, „The Guardian”, https://www.theguardian.com/world/2018/feb/16/turkey-sentences-six-journalists-life-imprisonment-failed-coup

Wprost (2016), Premier Turgi podsumowat represje po puczu, https:/ /www.wprost.pl/swiat/ 10019743/Premier-Turcji-podsumowal-represje-po-puczu-Zamknieto-ponad-4tys-firm.html [17.09.2017]

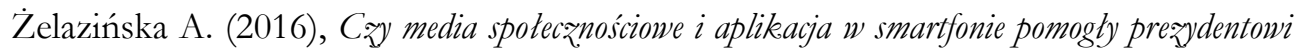
Turcji zatraymać pucz?, http://www.polityka.pl/tygodnikpolityka/swiat/1668794,1, czy-media-spolecznosciowe-i-aplikacja-w-smartfonie-pomogly-prezydentowi-turcjizatrzymac-pucz.read [03.12.2017] 